\section{DIFFERENCES IN THE PERCEIVED BENEFITS OF MEMBERSHIP AMONG TYPES OF SELF- HELP AND SUPPORT GROUPS}

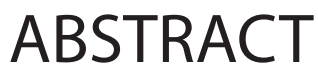

The article shows the results of the cross-sectional study on a national level in Slovenia aimed at examining the differences in the perceived benefits for members $(N=639)$ in self-help and support groups regarding the helping characteristics of the group, perceived empowerment, and member influence on the group among group types. The group types were formed by the criteria of the target population, i.e. the topic of the group. The results confirmed the expected significant differences according to the general aim of the groups among some, but not all of the group types regarding: a) two factors of a group's helping characteristics, i.e. disclosure and acceptance, and learning coping strategies; and b) two factors of perceived empowerment, i.e. assertiveness and competency, and enhanced knowledge about society; and c) regarding the extent of a member's

${ }^{1}$ Mija Marija Klemenčič Rozman, PhD, social pedagogue, E-mail: mija-marija. klemencic@guest.arnes.si
Received: March, 2015.

Accepted: November, 2015.

UDK: 159.913

DOI: $10.3935 /$ ljsr.v22i2.68

Mija Marija

Klemenčič Rozman ${ }^{1}$

University of Ljubljana

Faculty of Education

Department of Social Pedagogy
Key words:

self-help groups, support groups, membership, benefits. 
influence on the group. The findings suggest that active members are, in general, very satisfied with their groups, but the perceived benefits are not present to the same extent in all group types. The implications for further research and practice are being discussed.

\section{INTRODUCTION}

Self-help and support groups are two approaches which have gradually risen in numbers in Slovenia since 1991, amid the changing social system in the country, slowly drawing attention to the processes that take place in these groups. Self-help and support groups by definition differ, but the definitions embrace theoretically ideal types, while in reality the characteristics of both can be found among these groups interchangeably regardless of the theoretical borders between them (Farris Kurtz, 1997). The outcomes of the participation in groups have been the centre of interest of much research, but also of governments looking to reduce financing to at-risk populations (Balgopal, Ephros \& Vassil, 1986).

Studies on the outcomes of participation in self-help and support groups conducted in the 1980s revealed some general outcomes: reduced psychiatric symptomatology and use of professional services, increased coping skills, increased lifesatisfaction, and shorter hospital days (Farris Kurtz, 1997). In the 1990s the focus of research turned towards factors that contribute to affiliation and participation in self-help and support groups (ibid.). The overview of current studies on benefits, outcomes, or effects of membership participation shows that most of the studies still examine the benefit of the membership within a particular type of self-help or support group.

Research on support groups for family members/caregivers showed that members of a support group for family caregivers of people with schizophrenia experienced positive personal changes, such as new coping skills, positive characteristics of mutual support such as empowerment, but also some inhibitors of the group's development, such as overexpression of intense and negative feelings (Chien, Norman \& Thompson, 2006). Family members of patients with lifethreatening illnesses during palliative care who participated in a support group programme reported increased perceptions of preparedness and competence for caregiving and of rewards of caregiving compared to a non-participating group (Henriksson et al., 2012). Members of a videoconference support group for family caregivers of people with dementia showed trends towards improvement in several caregivers' domains, and reported less stress and more emotional support,

\section{2 articles}


M. M. Klemenčič Rozman: Differences in the perceived benefits of membership among...

empathy, and compassion (Guerriero Austrom et al., 2014). Caregivers of psychotic patients participating in support groups compared to non-participant caregivers showed a lower level of psychopathological characteristics on the dimension of interpersonal sensitivity, depression, (phobic) anxiety, hostility, and paranoid ideation (Mentis et al., 2014).

In the area of groups for parents of children, the study on a social comparison in the support group for parents of children with Duchenne Muscular Dystrophy revealed a wide range of positive and negative upward and downward social comparison on illness and coping dimensions (Hodges \& Dibb, 2010), while an analysis of narrative themes in a parental bereavement support group revealed that talking with members of the group about the death story, about coping/negotiating and talking in the group about experiences in communication with others outside the group enables parents' recovery after the death of the child (Umphrey \& Cacciatore, 2011).

In the area of research on the benefits of membership in self-help groups for women, a study regarding the empowerment of women in rural India showed that working women report (quantitative data) moderate to high levels on collectiveefficacy and self-efficacy, a proactive attitude, and self-esteem, while qualitative data also uncovered psychological stress (Moyle, Dollard \& Biswas, 2006). Furthermore, widowed and abandoned women in micro-credit self-help groups in rural India reported increased perception of self-efficacy beliefs (Newransky, Kayser \& Lombe, 2014). A support group for young women with disabilities influenced their sense of belonging within the group, such as increased self-confidence and disability pride, and in the world outside the group, such as communicating the empowered identity to friends, family, and community members (Mejias \& Gill, 2014).

A study of the effect of self-help group membership showed that participation in a group may possibly enhance the effects of psychiatric treatment on outcome in the terms of decreased numbers of admissions and days in hospital and increased satisfaction with work/education, while no differences in clinical and social outcome were detected (Burti et al., 2005). Another study revealed that membership in a 12-step self-help group for substance use problems was more intensive in a group of people with a history of physical and sexual abuse, compared to a group with no history of abuse, and was also a predictor for both groups for abstinence after a year (Schneider, Burnette \& Timko, 2008). Research on 12-step groups for adolescents after outpatient substance abuse treatment (compared to a control group) showed that it is important to link adolescents with higher severity to continuing care services, such as self-help groups in order to maintain the outcomes of the treatment (Gangi \& Darling, 2012). The study of the effects of an online support group for people with HIV/AIDS revealed benefits such as better planning, active 
coping, and instrumental and emotional support compared to non-users (Mo \& Coulson, 2009).

The findings of current studies presented underline the positive effects of membership, and in some cases, but not all, also the negative effects, (Chien, Norman \& Thompson, 2006; Moyle, Dollard \& Biswas, 2006; Stommel \& Koole, 2010; Hodges \& Dibb, 2010). Nevertheless, it is not possible to draw the conclusion that the benefits found are present in all kinds of self-help and support groups to the same extent. Despite that fact in the literature the benefits of group membership are often presented as general characteristics taking place in all kinds of groups (and sometimes, but less frequently also with the notion of negative effects; Balgopal, Ephros \& Vassil, 1986; Shopler \& Galinsky, 1995; Farris Kurtz, 1997). This generalisation lacks the power of insight in the outcomes of membership of different group types.

Therefore, the present study aims to determine if different types of self-help and support groups offer and emphasise different benefits in comparison to other types of self-help and support groups. For the purpose of this study, self-help and support group types were defined by the criteria of their target population, i.e. the main theme or topic that they cover. The comparison was performed regarding the helping characteristics of the group, perceived empowerment, and member influence on the group because these are frequent topics of research findings and because they represent the interest of the author. Helping characteristics in selfhelp and support groups are: giving support, imparting information, conveying a sense of belonging, communicating experiential knowledge, and teaching coping methods; while the ones specific to self-help groups are: identity transformation, empowerment, insight, reframing and formation of a new way of life (Farris Kurtz, 1997). It should be noted that other authors do frame them a bit differently (Katz, 1993; Schiff \& Bargal, 2000). While some authors state that becoming empowered is a benefit of a membership, others argue that benefits are an outcome of empowerment (Cheung, Mok \& Cheung, 2005), dividing it on three levels: intrapersonal, interpersonal, and extrapersonal empowerment. However, they don't explicate the theoretical framework of such a division.

The underlying thesis suggests that because self-help and support groups are formed to support and facilitate different target groups of population, and consequently have different goals of functioning, the benefits regarding the helping characteristics of the group, perceived empowerment, and member influence on the group differ among different group types according to their general aim of functioning.

\section{4 articles}




\section{METHOD}

\section{Participants}

Purposeful sampling was employed to detect participants. The insight in the population gained through the pilot study preceding the present research indicated three clusters of self-help and support groups in Slovenia: 1) self-help groups for elderly people, which are large in numbers and have their own clearinghouse; 2) self-help groups and support groups for different kinds of target groups, which are more than two of a kind, usually around 30 , among them AA with 50 groups as the largest; and 3) the cluster of self-help and support groups which are one of a kind or two, at maximum. The purposeful sampling was followed for each of the clusters. A total of 639 members of Slovenian self-help or support groups took part in the study, regardless of the length of their membership in the group. The baseline characteristics of participants are presented in Table 1.

For the purpose of this study, the group was assigned to one of five different group types by the criteria of the target population/topic of the group. The five group types were: 1) groups for parents or family members, 2) groups for patients of chronic disease and people with special needs, 3) groups for people with mental health problems and addictions, 4) groups for elderly people, and 5) groups for people in different life circumstances (this category included LGBT members, groups for young mothers, groups for divorced people, etc.).

Table 1. Baseline characteristics of the participants

\begin{tabular}{|c|c|c|}
\hline & M (SD) & n (\%) \\
\hline \multicolumn{3}{|l|}{ Gender $(N=632)$} \\
\hline Female & & $471(74.5)$ \\
\hline Male & & $161(25.5)$ \\
\hline Age $(\mathrm{N}=630)$ (range $17-95$ years) & $54.21(15.91)$ & \\
\hline \multicolumn{3}{|l|}{ Age groups $(\mathrm{N}=630)$} \\
\hline $16-25$ years & & $15(2.4)$ \\
\hline $26-35$ years & & $72(11.4)$ \\
\hline $36-45$ years & & $114(18.1)$ \\
\hline $46-55$ years & & $133(21.1)$ \\
\hline $56-65$ years & & $133(21.1)$ \\
\hline $66-75$ years & & $99(15.7)$ \\
\hline $76-85$ years & & $50(7.9)$ \\
\hline $86-95$ years & & $14(2.2)$ \\
\hline
\end{tabular}




\begin{tabular}{|c|c|c|}
\hline & M (SD) & n (\%) \\
\hline \multicolumn{3}{|l|}{ Education level $(\mathrm{N}=632)$} \\
\hline University or higher & & $139(22.0)$ \\
\hline High school & & $216(34.2)$ \\
\hline Vocational school & & $145(22.9)$ \\
\hline Primary school & & $106(16.8)$ \\
\hline Unfinished primary school & & $26(4.1)$ \\
\hline \multicolumn{3}{|l|}{ Employment $(\mathrm{N}=572)$} \\
\hline Retired & & $323(56.5)$ \\
\hline Employed & & $166(29.0)$ \\
\hline Unemployed & & $57(10.0)$ \\
\hline Homemaker & & $15(2.6)$ \\
\hline Student (university/high school) & & $11(1.9)$ \\
\hline \multicolumn{3}{|l|}{ Type of the group $(\mathrm{N}=625)$} \\
\hline Parents/family members & & $166(26.6)$ \\
\hline Chronic disease and special needs & & $139(22.2)$ \\
\hline Mental health problems and addictions & & $137(21.9)$ \\
\hline Elderly people & & $92(14.7)$ \\
\hline Different life circumstances & & $91(14.6)$ \\
\hline $\begin{array}{l}\text { Years of participation }(\mathrm{N}=618) \\
\text { (range: } 0-20 \text { years) }\end{array}$ & $4.75(4.67)$ & \\
\hline \multicolumn{3}{|l|}{ Frequency of participation $(\mathrm{N}=635)$} \\
\hline (Almost) each meeting & & $514(80.9)$ \\
\hline $3 / 4$ of all meetings & & $74(11.7)$ \\
\hline $1 / 2$ of all meetings & & $36(5.7)$ \\
\hline Less than $1 / 2$ of all meetings & & $11(1.7)$ \\
\hline \multicolumn{3}{|l|}{ A wish to stop participation in the future $(\mathrm{N}=632)$} \\
\hline Yes & & $47(7.4)$ \\
\hline No & & $585(92.6)$ \\
\hline $\begin{array}{l}\text { General satisfaction with the group }(\mathrm{N}=630) \\
\text { (range } 0-10 \text { ) }\end{array}$ & $8.44(1.74)$ & \\
\hline
\end{tabular}

\section{Procedures}

The present study was a part of a larger research on self-help and support groups in Slovenia which consisted of two phases. The first phase was a study of the organisational characteristics of these groups with the sample of group leaders or facilitators. The author invited 237 group leaders/facilitators by phone to participate in the study and fill in the Questionnaires for Group Leaders/Facilitators (164 responded). Besides their own participation in the study, group leaders/facilitators were asked to help in the second phase by handing out the Questionnaires

\section{6 articles}


M. M. Klemenčič Rozman: Differences in the perceived benefits of membership among...

for Group Members to the members of their group at the first/next group meeting. Each questionnaire for group members had a pre-stamped envelope so that group members returned the questionnaire by themselves, and social control by group leaders/facilitators was avoided. All together 1680 questionnaires were sent out through the leaders/facilitators to group members, 686 were sent back, and 47 of these were not included in the data analysis due to the lack or inconsistency of the answers.

\section{Measures}

\section{Socio-demographic measures and characteristics of the membership}

The first set of questions asked for participants' gender, age, education level, employment status, type of group, length of membership, frequency of participation at the group meetings, and anticipated ending of the membership at some point in the future.

\section{Satisfaction with self-help or support group}

The overall satisfaction with the group was measured on an 11-point scale from $0-10(0=$ extremely dissatisfied, $10=$ extremely satisfied $)$ following the example of Schiff and Bargal (2000). The authors suggest that it would have been preferable to use more than a one-item scale, but at the same time are opposed to it by pointing out the studies which show that validity and reliability of a single item scale of satisfaction are comparable to a multiple-item scale (Scarpello \& Campbell, 1983 in Schiff \& Bargal, 2000), and the measurements are as useful (Crooker \& Near, 1998 in Schiff \& Bargal, 2000).

\section{Group helping characteristics}

The helping characteristics in the group were measured on a set of 22 items (example of items included: "The group helps me find new helping strategies." and "I share my life experiences with other members of the group.") with a 4-point scale from 1 - 4 ( 1 = I completely disagree, 4 = I completely agree), following the example of Schiff and Bargal (2000), where the authors derived six factors by conducting a factor analysis. Because the scale was translated in Slovene and adapted (reversed items, a 4-point scale instead of a 5-point in the original), a factor analysis was conducted on data gathered. A principal component analysis (Oblimin rotation) by eigenvalues above 1 showed that the three extracted factors explain $51.4 \%$ of variance of all variables (15) included in the analysis: the first factor disclosure and acceptance in the group explains $35.3 \%$ of variance, the second, learning coping strategies, $8.9 \%$, and the third, exchange of knowledge and experiences, $7.2 \%$. 
The KMO statistic is 0.89 , Barlett's test is significant at $\mathrm{p} \leq 0.001$, and the determinant of the correlation matrix is 0.012 .The Cronbach a for the subscale of which items constitute the first factor is 0.81 , for the subscale for the second 0.76 , and the third 0.61 . In the analysis of the present study the results of these factors are being used. Reversed items (7) were excluded after the first conducted analysis, giving the solution of five factors, where the second factor could be interpreted as a reversed value of the first one, while scales loaded with the last factors were unreliable.

\section{Personal empowerment}

Personal empowerment as an outcome of the participation in a self-help or support group was measured on a set of 20 items with 4-point scale ( $1=1 \mathrm{com}$ pletely disagree, $4=$ I completely agree), as presented in the study of Cheung, Mok and Cheung (2005), (see also Mok, 2001). The items were phrased as shown in the following examples: "Since joining the group I became more positive." or "Since joining the group / became more decisive in taking actions". Like the previously described scale this one was also translated into Slovene and adapted (different reversed items, a 4-point scale instead of a 6-point in the original), and therefore a factor analysis was conducted on the data gathered. The principal component analysis (Oblimin rotation) for eigenvalues above 1 showed that three extracted factors explain $51 \%$ of the variance of all variables: the first factor integrative viewpoint on one's qualities and weaknesses explains $28.1 \%$ of variance, the second, increased assertiveness and competency, $17.1 \%$, and the third, enhanced knowledge about the society, $5.8 \%$. The KMO statistic is 0.90 , Barlett's test is significant at $p \leq 0.001$, and the determinant of the correlation matrix is 0.001 . The Cronbach a for the subscales where items constitute the first, second, and third factors were $0.81,0.85$, and 0.76 , respectively. In the analysis of the present study the results of these factors are being used.

\section{Member influence on the group}

The extent of a member's influence on the group was measured on a set of 9 items with 4-point scale (points defined as in the scales above), which was composed by author for the purpose of this research. Examples of the items included in this scale: "When there comes to disagreements in the group, everyone has a chance to tell his/her opinion" and "There are some topics in the group that are forbidden to talk about". To check the underlying dimensions, a principal component analysis (Oblimin rotation) for eigenvalues above 1 was conducted, and showed one interpretable factor which explains $44.1 \%$ of variance (one item was excluded due to too low intercorrelation with other variables). The Kaiser-Meyer-Olkin (KMO) sta-

\section{8 articles}


M. M. Klemenčič Rozman: Differences in the perceived benefits of membership among...

tistic is 0.85, Barlett's test is significant at $p \leq 0.001$, and the determinant of the correlation matrix is 0.101 . The Cronbach a for the scale is 0.81 .

\section{RESULTS AND DISCUSSION}

\section{Members' general satisfaction with the group}

To see if the overall or general satisfaction with the group differs among group types, an ANOVA was conducted. Table 2 shows the descriptive statistics for variable general satisfaction with the group. The Leven's statistic was non-significant ( $p>0.05)$, and the differences between types of groups were also non-significant, $F(4,611)=1.688, p>0.05$. It can be concluded that the differences between the five types of groups were not proven.

Table 2. Descriptive statistics for variable general satisfaction with the group

\begin{tabular}{|c|c|c|c|c|c|c|c|c|}
\hline & \multirow{2}{*}{$\mathbf{N}$} & \multirow{2}{*}{$\mathbf{M}$} & \multirow{2}{*}{ SD } & \multirow{2}{*}{ SeM } & \multicolumn{2}{|c|}{$\begin{array}{l}\text { 95\% Confidence } \\
\text { Interval for M }\end{array}$} & \multirow{2}{*}{ Min } & \multirow{2}{*}{ Max } \\
\hline & & & & & $\begin{array}{l}\text { Lower } \\
\text { Bound }\end{array}$ & $\begin{array}{l}\text { Upper } \\
\text { Bound }\end{array}$ & & \\
\hline $\begin{array}{l}\text { Mental health } \\
\text { problems and } \\
\text { addictions }\end{array}$ & 136 & 8.48 & 1.450 & 0.124 & 8.23 & 8.72 & 5 & 10 \\
\hline $\begin{array}{l}\text { Chronic disease } \\
\text { and special needs }\end{array}$ & 136 & 8.25 & 1.581 & 0.136 & 7.98 & 8.52 & 0 & 10 \\
\hline $\begin{array}{l}\text { Parents/family } \\
\text { members }\end{array}$ & 165 & 8.65 & 1.324 & 0.103 & 8.45 & 8.86 & 2 & 10 \\
\hline $\begin{array}{l}\text { Different life } \\
\text { circumstances }\end{array}$ & 88 & 8.47 & 1.493 & 0.159 & 8.15 & 8.78 & 4 & 10 \\
\hline Elderly people & 91 & 8.30 & 1.560 & 0.164 & 7.97 & 8.62 & 4 & 10 \\
\hline Total & 616 & 8.45 & 1.474 & 0.059 & 8.33 & 8.56 & 0 & 10 \\
\hline
\end{tabular}

All of the participants in general rated their satisfaction higher than 8 (on the scale from 0 to 10), which is considerably high. Of course these results reflect the situation among active members of the groups. Participation in self-help and support groups is usually, or at least mostly, voluntary, and therefore people who are less, or not, satisfied with the group end their membership whenever they want. Nevertheless, even if the rating is obtained from active members of the groups, the rate of satisfaction above 8 can be considered as high. However, one can speculate that if the participants who after some time ended their membership were included in the study, the results would be different. 


\section{Helping characteristics of the group}

The three factors of the helping characteristics of the group (disclosure and acceptance, learning coping strategies, and exchange of knowledge and experiences) were included in the analysis employing MANOVA (multivariate analysis of variance) to detect the effect of the type of self-help or support group on the perceived helping characteristics of the group. Mean and standard deviation is represented for each of three factors with regard to group type in Table 3.

Table 3. Mean (M) and Standard Deviation (SD) of the factor scores for disclosure and acceptance, learning coping strategies and exchange of knowledge and experiences with regard to group type $(\mathrm{N}=538)$

\begin{tabular}{lccccc}
\hline & $\begin{array}{c}\text { MH\&A } \\
(\mathbf{N}=\mathbf{1 2 8})\end{array}$ & $\begin{array}{c}\mathbf{C D \& S N} \\
\mathbf{( N = 1 1 6 )}\end{array}$ & $\begin{array}{c}\mathbf{P} / \mathbf{F M} \\
\mathbf{( N = 1 4 5 )}\end{array}$ & $\begin{array}{c}\mathbf{D L C} \\
\mathbf{( N = 7 7 )}\end{array}$ & $\begin{array}{c}\text { EP } \\
\mathbf{( N = 7 2 )}\end{array}$ \\
\hline Disclosure and & 0.146 & -0.072 & 0.140 & -0.039 & -0.346 \\
acceptance & 0.953 & 0.959 & 1.051 & 1.097 & 0.874 \\
\hline Learning & 0.206 & -0.165 & 0.171 & 0.017 & -0.441 \\
$\begin{array}{l}\text { coping } \\
\text { strategies }\end{array}$ & 0.891 & 0.949 & 1.002 & 0.983 & 1.127 \\
\hline $\begin{array}{l}\text { Exchange of } \\
\text { knowledge and }\end{array}$ & 0.045 & 0.016 & 0.053 & -0.064 & -0.152 \\
experiences & 0.935 & 0.922 & 1.056 & 1.148 & 0.963 \\
\hline
\end{tabular}

LEGEND:

MH\&A = Mental health problems and addictions, CD\&SN = Chronic disease and special needs,

$\mathrm{P} / \mathrm{FM}=$ Parents/family members, $\mathrm{DLC}=$ Different life circumstances, $\mathrm{EP}=$ Elderly people

A significant multivariate main effect for types of the group was found, Wilks' $\lambda$ $=0.941, F(12,1405)=2.736, p<0.01$, and Leven's tests of equality of error variances were non-significant for each of the factors of helping characteristics in the group. A test of between subject effects indicated a significant difference between the types of self-help and support groups regarding disclosure and acceptance in the group $(F(4,533)=3.771, p<0.01)$, and learning coping strategies $(F(4,533)=$ $7.018, p<0.001)$, while no significant differences were found in terms of exchange of knowledge and experiences.

In terms of disclosure and acceptance in the self-help or support group, a post hoc analysis (Hochberg's GT2 procedure) revealed significant differences among self-help and support groups for elderly people $(M=-0.35, S D=0.87)$ and self-help and support groups for people with mental health problems and addictions ( $M=$ $0.15, S D=0.95)$, as well as self-help and support groups for elderly people and self- 
help and support groups for parents or family members $(M=0.14, S D=1.05)$. In both cases the tests were significant at level $p<0.01$. In other words, members of groups for elderly people experience less disclosure and acceptance in the group compared to members of the groups for people with mental health problems and addictions and members of the groups for parents or family members.

Self-help groups and support groups for elderly in Slovenia merely focus on companionship, and are mostly highly structured in the sense of activities (singing songs, talking about everyday life, going on a trip) with the main aim to help older people to maintain a better quality of their free time. While self-help and support groups for people with mental health problems and addictions mainly focus on sharing one's experience in order to overcome this state or to cope with it better, the groups (of their) family members/parents focus either on the situation of a family member of an addicted person, or on receiving better understanding and managing better one's own or one's family member's difficulties in (mental) health arising from a specific diagnosis. Therefore, it can be said that these groups are immensely different according to their aims. While in the groups for elderly people sharing one's experiences isn't performed on such an intimate level, the other two types of the groups focus exactly on that aspect.

In terms of learning coping strategies in self-help or support groups, post hoc analysis (Hochberg's GT2 procedure) revealed significant differences among selfhelp and support groups for elderly people $(M=-0.44, S D=1.13)$ and three other types of the groups: self-help and support groups for people with mental health problems and addictions $(M=0.21, S D=0.89)$, self-help and support groups for parents or family members $(M=0.17, S D=1.00)$, and self-help and support groups for different life circumstances $(M=0.02, S D=0.98)$, with the first two mentioned the differences were significant at level $p<0.001$, and with the last group at $p$ $<0.05$. So, members of the groups for elderly people reported significantly less learning of coping strategies than members of all other groups, except members of the groups for people with chronic diseases or special needs. But the latest ( $M$ $=-0.17, S D=0.95$ ) differed in terms of learning coping strategies significantly ( $p$ $<0.05$ ) from members of the groups for people with mental health problems and addictions.

Taken together, these results suggest that groups for elderly people are the type of group which offers their members far fewer new strategies for coping with one's problems, probably due to their main focus being companionship. This, of course, doesn't imply that they don't offer their members any learning of coping strategies, but the amount of this learning is significantly smaller compared to the first three groups. Meanwhile, self-help and support groups for people with mental health problems and addictions, which have the highest amount of learning cop- 
ing strategies, are the ones which differ significantly from the two of the groups with the least amount of learning coping strategies, as reported by their members. The reason for these results could be the fact that the dimension learning coping strategies, addressed the importance of the group on learning how to cope and control one's life, also compared to professional help, while in groups for chronic disease and special needs: 1) coping and gaining control over one's life is not at the centre of the focus, and 2) professional help is usually welcomed because it helps members to understand their illness or handicap in a more comprehensive way.

\section{Perceived personal empowerment}

Similarly, a MANOVA was conducted to detect the effect of the type of self-help or support group on three aspects of empowerment: 1) an integrative viewpoint on one's qualities and weaknesses, 2) increased assertiveness and competency, and 3) enhanced knowledge about society. Table 4 shows mean and standard deviation for each of three factors with regard to group type.

Table 4. Mean (M) and Standard Deviation (SD) of the factor scores for an integrative viewpoint on one's qualities and weaknesses, increased assertiveness and competency, and enhanced knowledge about society with regard to group type $(\mathrm{N}=515)$

\begin{tabular}{lccccc}
\hline & $\begin{array}{c}\text { MH\&A } \\
(\mathbf{N}=\mathbf{1 1 8})\end{array}$ & $\begin{array}{c}\text { CD\&SN } \\
\mathbf{( N = 1 0 8 )}\end{array}$ & $\begin{array}{c}\text { P/FM } \\
(\mathbf{N}=\mathbf{1 4 7})\end{array}$ & $\begin{array}{c}\text { DLC } \\
(\mathbf{N}=\mathbf{7 5})\end{array}$ & $\begin{array}{c}\text { EP } \\
\mathbf{( N = 6 7 )}\end{array}$ \\
\hline Integrative viewpoint & 0.180 & -0.009 & 0.043 & -0.081 & -0.241 \\
on one's qualities and & 1.008 & 0.815 & 1.120 & 0.946 & 1.015 \\
weaknesses & 0.180 & -0.237 & 0.157 & -0.075 & -0.128 \\
\hline Increased assertiveness & 0.851 & 0.963 & 0.972 & 1.113 & 1.044 \\
and competency & -0.180 & 0.210 & 0.001 & 0.303 & -0.317 \\
\hline Enhanced knowledge & 0.995 & 0.881 & 1.055 & 1.009 & 0.927 \\
\hline
\end{tabular}

LEGEND:

MH\&A = Mental health problems and addictions, CD\&SN = Chronic disease and special needs, $\mathrm{P} / \mathrm{FM}=$ Parents/family members, DLC = Different life circumstances, $\mathrm{EP}=$ Elderly people

A significant multivariate main effect for types of the group was found, Wilks' $\lambda=0.899, F(12,1344)=4.584, p<0.001$, and Leven's tests of equality of error variances were non-significant for each of the factors of perceived personal empowerment. A test of between subject effects showed no significant differences in terms of an integrative viewpoint on one's qualities and weaknesses, while a significant difference among types of self-help and support groups regarding increased assertiveness and competency $(F(4,510)=3.939, p<0.01)$, and enhanced knowledge about society $(F(4,510)=5.744, p<0.001)$ were found.

\section{2 articles}


In terms of increased assertiveness and competency gained through a membership in a self-help or support group, a post hoc analysis (Hochberg's GT2 procedure) revealed significant differences among self-help and support groups for people with chronic disease or special needs $(M=-0.24, S D=0.96)$, and two other self-help and support groups with the highest mean of scores for increased assertiveness and competency: groups for people with mental health problems and addictions $(M=0.18, S D=0.85)$ and self-help and support groups for parents or family members $(M=0.16 S D=0.97)$. In both cases the tests were significant at level $p<0.05$. Taken together, members of groups for people with chronic disease and special needs report importantly less increased assertiveness and competency gained through membership compared to members of the groups for people with mental health problems and addictions and members of the groups for parents or family members.

The factor of increased assertiveness and competency included the aspects of one's attitudes concerning openness, helping others, secureness of problemsolving etc., all of these being oriented to personal changes and assertive positioning which represent the majority of the goals in self-help and support groups for people with mental health problems and addictions and groups for parents or family members. Meanwhile, self-help and support groups for chronic patients and people with special needs are mostly oriented towards gaining information about the illness or handicap, and learning how to live with it in a way to increase one's well-being. Therefore, it can be understood that increased assertiveness and competency is far more present in groups for people with mental health problems and addiction and their members because these groups address (stigmatised) behaviour which is considered by society as something that can be changed or at least controlled if the person decides to, while in groups for chronic patients and people with special needs the central part of the attention goes to the medical or physical condition which cannot be changed except by one's own will.

In terms of enhanced knowledge about society gained through membership in a self-help or support group, a post hoc analysis (Hochberg's GT2 procedure) revealed significant differences among self-help and support groups for people in different life situations $(M=0.30, S D=1.01)$ and two self-help and support groups with the lowest mean of scores for enhanced knowledge about society: groups for people with mental health problems and addictions $(M=-0.18, S D=1.00)$, and self-help and support groups for elderly people $(M=-0.32, S D=0.93)$. In both cases the tests were significant at level $p<0.01$. The last two mentioned groups also differed significantly from the group for people with chronic disease or special needs $(M=0.21, S D=0.88$ ); the differences between this group and the group for 
people with mental health problems or addictions were significant at level $p<$ 0.05 , and with the group for elderly people at level $p<0.01$.

Self-help and support groups with people in different life situations (for example LGBT support groups or support groups for mothers-to-be) and groups for people with chronic diseases and people with special needs are all focussed on increasing one's well-being by receiving a more equal position in society, equal rights, and financial or other instrumental help, or the benefits given by society. These topics were covered by the aspect of enhanced knowledge about society. On the other hand, groups for people with mental health problems and addictions are mostly focussed on personal change and coping with one's situation, and some of them explicitly distance themselves from social affairs (e.g. AA being completely apolitically oriented in the broadest sense of the word). All of these can be explanations for the results obtained. However, the reason for the difference with groups for elderly people probably lies in the fact that they are oriented at companionship for elderly people, and not at overcoming the stigmatised status of older people in society.

\section{Member influence on the group}

To see if a member's influence on the group differs among the group types, an ANOVA was conducted. The Leven's statistics were non-significant $(p>0.05)$, the differences between types of groups $F(4,565)=3.148$ were significant at level $p<$ 0.05 . Hochberg's GT2 post hoc test showed significant differences, $p<0.05$, among self-help and support groups for people with mental health problems and addictions $(M=0.16, S D=1.02)$ and groups for people with chronic disease or special needs $(M=-0.23, S D=0.97$ ). Among all types of the self-help and support groups including the groups for people with mental health problems and addictions are by far the more user-led, or at least greatly emphasise the users' perspective. On the other hand, groups for people with chronic disease or special needs are mostly led by (mental) health professionals, and are closer to a professional-centred role of group leader.

\section{CONCLUSIONS}

In general, members of self-help and support groups tend to be very satisfied with the groups in which they participate. Of course, these results can be biased because people who responded (participation was strictly voluntary) could be the ones who are very much engaged in self-help and support groups. Nevertheless, the level of satisfaction with the group among the respondents was very high. But

\section{4 articles}


some expected differences between types of self-help and support groups were shown regarding helping characteristics of the group, perceived empowerment, and a member's influence on the group.

Disclosure and acceptance turned out to be significantly less represented in self-help and support groups for elderly people compared to the groups for people with mental health problems and addictions and groups for parents or family members. The differences in the goals, in our opinion, are accounted for in these findings. Since groups for elderly people focus mostly on companionship and sharing every-day situations, the other two types are highly oriented towards members' sharing their personal experiences and feelings in the group.

The aim of companionship in groups for elderly people is again probably the reason why they also differ greatly in the dimension of learning coping strategies from the groups with a higher orientation on changing one's life perspective, which are: groups for people with mental health problems and addictions, groups for parents or family members, and groups for different life circumstances. Among those, self-help and support groups for people with mental health problems and addictions take the highest place and immensely differ in that dimension from the two of the groups with the least amount of learning coping strategies: groups for people with chronic disease and special needs, and groups for elderly people.

Since learning coping strategies is a dimension that indicated learning how to cope with and control one's life, also in terms of group help compared to professional help, it is understandable that it is less present in the groups for chronic disease and special needs because it is not at the centre of the group focus, and because professional help is usually welcomed in these groups in order to help members understand their illness or handicap in a more comprehensive way, while in the groups for elderly people the reason again, from our interpretation of the data, is that the aim of the group is companionship.

Assertiveness and competency is the dimension oriented towards personal changes and assertive position, which represent the majority of the goals in selfhelp and support groups for people with mental health problems and addictions and group of parents or family members. Meanwhile groups for people with chronic disease and special needs are mostly oriented towards gaining information about the illness or handicap and learning how to live with it in a way to increase one's well-being. That is one of the reasons their members report significantly less increased assertiveness and competency gained through membership, compared to the two previously mentioned groups.

As for the dimension of enhanced knowledge about society (which included knowledge on one's rights in society, etc.), the picture becomes different. Self-help and support groups with people in different life situations and the groups for peo- 
ple with chronic diseases and people with special needs offer their members more of it, because they are focussed on increasing one's well-being by receiving a more equal position in society than the groups for people with mental health problems and addictions, which are not oriented at one's position in society, and sometimes even have restrictions on these topics (e.g. AA). However, the reason for the difference with groups for elderly people probably lies in the fact that they are oriented at companionship for elderly people and not at achieving a better status of older people in society.

This leads us to the question of whether the groups included for elderly people, which are mainly oriented towards companionship, can in fact be considered a special subgroup of self-help or support groups or perhaps they tend to be more of a form of organised socialisation groups for leisure. To answer this question the analysis of the groups' programme should be undertaken, but on the level of the research design the answer is clear. The self-help and support groups invited were the groups which called or considered themselves as such. The groups for elderly people included in the research clearly state themselves as self-help groups for the elderly. Because self-help groups emerge via the self-organising principle, i.e. bottom-up, variation among the groups is huge. Of course from the viewpoint of an outsider it can be speculated that they don't match all the criteria of self-help groups, but yet again when we put ourselves in the position to access and legitimate the phenomena as outsiders, it can be seen that the phenomena is ruled by the self-organising principle.

Regarding the extent of member influence on groups, the groups for people with mental health problems and addictions -which are mostly user-led or at least greatly emphasise the users' perspective - turned out to be different from groups for people with chronic disease or special needs mostly led by (mental) health professionals, which are closer to the professional-centred role of the group leader.

As previously mentioned, one of the limits of this study is the strictly voluntary participation of the respondents which can lead to a biased picture. Another limitation of the study could be that the groups included were not 'carefully' selected by the criteria of self-help versus support groups, and perhaps that the overall picture would be different if the analysis were to be done respectively for each. Despite the theoretical schema of this argument, literature proves that these two types of the group overlap when coming across work with self-help or support groups in real-life situations (Farris Kurtz, 1997) and the pilot study preceding this one also confirmed the same findings in Slovenian self-help and support groups.

In the discussion of the results of this study all explanations of the group types were based on models of Slovenian types of self-help and support groups. It can be speculated that roughly similar conclusions could be foreseen for other coun-

\section{6 articles}


tries, where the types of groups have similar structures. If we take groups for substance abuse, then we believe similar findings can be expected in countries where the type of self-help groups for people with addictions includes mainly 12-step groups, like in Slovenia, and where other approaches which address the position of minority and alcoholics in society (e.g. Men in Recovery in the USA; Hopson, 1996) are not widely represented. Suffice it to say, if the types of the groups are structured much differently from the ones used in this study (e.g. self-help groups for Indian rural women), expectations of different conclusions would be reasonable.

Concerning types of groups, some propositions for further research could be made. Even though the types of self-help and support groups were constructed by the criteria of the target population, there lies a question about underlying dimensions, which were addressed by researchers who dealt with typologies of mutual-aid groups (Schubert \& Borkman, 1991; Shopler \& Galinsky, 1995; Farris Kurtz, 1997). The answers to questions about the programme of the groups, organisational characteristics, the rate of user-led activities in the group, etc. could provide important information on plausible subtypes within the types of the group used in the study. We get the impression the subgroups with similar programmes, ideology, and organisational characteristics would have non-significant results regarding dependent variables. In other words, the question of the interaction between characteristics mentioned and group types is of interest for further research.

To sum up, it can be said that people in different types of self-help and support groups gain different qualities. Since active members are, in general, very satisfied with their groups, it can be concluded that they get what they need, but what they need in some aspects differs greatly among group types. Therefore, it is not unreasonable to underline the importance of careful stating of the benefits of self-help and support groups. They offer many benefits to their members, but these benefits are not present to the same extent in all group types.

These findings also open the question for potentially new models of self-help and support groups which would aim at offering benefits for a target population which current groups cannot sufficiently enable (for example: support groups for elderly people which would address the ageism and social exclusion of old people). In order to be based on users' needs, research would be beneficial on expectations of members who estimated that the group in which they participated for some time didn't answer their motives and subsequently ended their participation. Combined with the results of the present study the integration of findings could help to plan models of self-help and support groups for specific target populations in order to focus on the aspects that current groups don't cover (enough). This would lead to an extension of alternatives for people seeking the right form of self-help or support group for them. 


\section{REFERENCES}

1. Balgopal, P. R., Ephross, P. H. \& Vassil, T. V. (1986). Self-help groups and professional helpers. Small Group Research, 17 (2), 123-137.

2. Burti, L., Amaddeo, F., Ambrosi, M., Bonetto, C., Cristofalo, D., Ruggeri, M. \&Tansella, M. (2005). Does additional care provided by a consumer self-help group improve psychiatric outcome? A study in an italian community-based psychiatric service. Community Mental Health Journal, 41 (6), 705-720.

3. Cheung, Y. W., Mok, B. H. \& Cheung, T. S. (2005). Personal empowerment and life satisfaction among self-help group members in Hong Kong. Small Group Research, 36 (3), 354-377.

4. Chien, W. T., Norman, I. \& Thompson, D. R. (2006). Perceived benefits and difficulties experienced in a mutual support group for family carers of people with schizophrenia. Qualitative Health Research, 16 (7), 962-981.

5. Farris Kurtz, L. (1997). Self-help and support groups: A handbook for practitioners. Thousand Oaks, London, New Delhi: Sage Publication.

6. Gangi, J.\& Darling, C. A. (2012). Adolescent substance-use frequency following self-help group attendance and outpatient substance abuse treatment. Journal of Child \& Adolescent Substance Abuse, 21, 293-309.

7. Guerriero Austrom, M. Geros, K. N., Hemmerlein, K., McGuire, S. M., Gao, S., Brown, S. A., Callahan, C. M. \& Clark, D. O. (2014). Use of a multiparty web based videoconference support group for family caregivers. Dementia, $0(0)$, $1-9$.

8. Henriksson, A., Årestedt, K., Benzein, E., Ternestedt, B.-M. \& Andershed, B. (2012). Effects of a support group programme for patients with life-threatening illness during ongoing palliative care. Palliative Medicine, 27 (3), 257-264.

9. Hodges, L. \& Dibb, B. (2010). Social comparison within self-help groups: Views of parents of children with duchenne muscular dystrophy. Journal of Health Psychology, 15 (4), 483-492.

10. Hopson, R. E. (1996). The 12-Step Program. In: Shafranske, E. P. (ed.), Religion and the clinical practise of psychology. Washington, DC: American Psychological Association, 533-558.

11. Katz, A. H. (1993). Self-help in America: A social movement perspective. New York: Twayne Publishers.

12. Mejias, N. J. \& Gill, C. J. (2014). Influence of a support group for young women with disabilities on sense of belonging. Journal of Counseling Psychology, 61 (2), 208-220.

13. Mentis M, Messinis, L., Kotrotsiou E., Angelopoulos, N. V, Marneras, C., Papathanasopoulos, P. \& Dardiotis, E. (2014). Efficacy of a support group intervention on psychopathological characteristics among caregivers of 
M. M. Klemenčič Rozman: Differences in the perceived benefits of membership among...

psychotic patients. International Journal of Social Psychiatry, Published online before print, 1-6, DOI: 10.1177/0020764014547075

14. Mo, K. H. P. \& Coulson, N. S. (2009). Living with HIV/AIDS and Use of Online Support Groups. Journal of Health Psychology, 15 (3), 339-350.

15. Mok, B.-H. (2001). Cancer self-help groups in China: A study of individual change, perceived benefit, and community impact. Small Group Research, $32(2), 115-132$.

16. Moyle, T. L., Dollard, M. \& Narayan Biswas, S. (2006). Personal and economic empowerment in rural indian women: A self-help group approach. International Journal of Rural Management, 2 (2), 245-266.

17. Newransky, C., Kayser, K. \& Lombe, M. (2014). The development of self-efficacy beliefs of widowed and abandoned women through microcredit self-help groups: The case of rural South India. Journal of Social Service Research, 40, 201-214.

18. Schubert, M. A. \& Borkman, T. J. (1991). An organizational typology for selfhelp groups. American Journal of Community Psychology, 19 (5), 769-787.

19. Schiff, M. \& Bargal, D. (2000). Helping characteristics of self-help and support groups. Their contribution to participants'subjective well-being. Small Group Research, 31 (3), 275-304.

20. Schneider, R., Burnette, M. \& Timko, C. (2008). History of physical or sexual abuse and participation in 12-step self-help groups. The American Journal of Drug and Alcohol Abuse, 34 (5), 617-625.

21. Shopler, J. H. \& Galinsky, M. J. (1995). Expanding our view of support groups as open systems. In: Galinsky, M. J. \& Shopler, J. H. (eds.), Support groups: Current perspectives on theory and practise. New York, London: The Haworth Press Inc., 3-10.

22. Stommel, W. \& Koole, T. (2010). The online support group as a community: A micro-analysis of the interaction with a new member. Discourse Studies, 12 (3), 357-378.

23. Umphrey, L. R. \& Cacciatore, J. (2011). Coping with the ultimate deprivation: Narrative themes in a parental bereavement support group. Omega, 63 (2), $141-160$. 
Ljetopis socijalnog rada 2015., 22 (3), 351-370 str.

Mija Marija Klemenčič Rozman

Sveucilišste u Ljubljani

Pedagoški fakultet

Odsjek za socijalnu pedagogiju

\title{
RAZLIKE U PERCIPIRANIM KORISTIMA ČLANSTVA U RAZLIČITIM TIPOVIMA GRUPA ZA SAMOPOMOĆ I PODRŠKU
}

\begin{abstract}
SAŽETAK
U članku su prikazani rezultati transferzalnog istraživanja na nacionalnoj razini u Sloveniji, čiji je cilj bio ispitati razlike u percipiranim koristima za članove $(N=639)$ grupa za samopomoć i grupa za podršku koje se odnose na pomažuće značajke grupe, percipirano osnaživanje i utjecaj člana na grupu u različitim tipovima grupa. Tipovi grupa formirani su prema kriteriju ciljne populacije, tj. teme oko koje se grupa okuplja. Rezultati su potvrdili očekivane značajne razlike ovisno o općem cilju grupe kod nekih, ali ne, i svih tipova grupa vezano uz: a) dva čimbenika pomažućih značajki grupe, tj. razotkrivanje i prihvaćanjes jedne te učenje strategija za prevladavanje poteškoća s druge strane; b) dva čimbenika percipiranog osnaživanja, tj. upornost i sposobnost te proširivanje znanja o društvu i c) razmjer utjecaja člana na grupu. Rezultati pokazuju da su aktivni članovi općenito vrlo zadovoljni svojim grupama, no percipirane koristi nisu u istoj mjeri prisutne u svim tipovima grupa. Prikazane su implikacije za daljnje istraživanje i primjenu u praksi.
\end{abstract}

Ključne riječi: grupe za samopomoć, grupe za podršku, članstvo, koristi. 